\begin{tabular}{l|l|l|l}
$\begin{array}{l}\text { Case Reports in } \\
\text { Ophthalmology }\end{array}$ & $\begin{array}{l}\text { Case Rep 0phthalmol 2010;1:1-4 } \\
\text { Dol: } 10.1159 / 000313788\end{array}$ & Published online: May 12, 2010 & $\begin{array}{l}\text { ○ 2010 Karger AG, Basel } \\
\text { ISSN 1663-2699 } \\
\text { www.karger.com/cop }\end{array}$ \\
\hline
\end{tabular}

\title{
Case Report of Bullous Pemphigoid following Fundus Fluorescein Angiography
}

\author{
Goktug Demircia Gulsen Tukenmez Demirci ${ }^{b}$ \\ Gokhan Gulkilikc \\ ${ }^{a}$ Department of Ophthalmology, Duzce Goverment Hospital, Duzce, ${ }^{b}$ Department \\ of Dermatology, Baskent University Hospital, and 'Department of Ophthalmology, \\ Sisli Etfal Research Hospital, Istanbul, Turkey
}

\section{Key Words}

Angiography $\cdot$ Side effect $\cdot$ Pemphigoid $\cdot$ Fluorescein

\author{
Abstract \\ Purpose: To report a first case of bullous pemphigoid (BP) following intravenous \\ fluorescein for fundus angiography.
}

Clinical Features: A 70-year-old male patient was admitted to the intensive care unit with $\mathrm{BP}$ and sepsis. He reported a history of fundus fluorescein angiography with a prediagnosis of senile macular degeneration 2 months prior to presentation. At that time, fluorescein extravasated at the antecubital region. Following the procedure, pruritus and erythema began at the wrists bilaterally, and quickly spread to the entire body. The patient also reported a history of allergy to human albumin solution (Plamasteril ${ }^{\circledR}$; Abbott) 15 years before, during bypass surgery. On dermatologic examination, erythematous patches were present on the scalp, chest and anogenital region. Vesicles and bullous lesions were present on upper and lower extremities. On day 2 of hospitalization, tense bullae appeared on the upper and lower extremities. The patient was treated with oral methylprednisolone $48 \mathrm{mg}$ (Prednol ${ }^{\circledR}$; Mustafa Nevzat), topical clobetasol dipropionate $0.05 \%$ cream (Dermovate ${ }^{\circledR}$; Glaxo SmithKline), and topical $4 \%$ urea lotion (Excipial Lipo ${ }^{\circledR}$; Orva) for presumptive bullous pemphigoid. Skin punch biopsy provided tissue for histopathology, direct immunofluorescence examination, and salt extraction, which were all consistent with BP. After 1 month, the patient was transferred to the intensive care unit with sepsis secondary to urinary tract infection; he died 2 weeks later from sepsis and cardiac failure.

Conclusions: To our knowledge, this is the first reported case of BP following fundus fluorescein angiography in a patient with known human albumin solution allergy. Consideration should be made to avoid fluorescein angiography, change administration route, or premedicate with antihistamines in patients with known human albumin solution allergy. The association between fundus fluorescein angiography and BP should be further investigated. 


\begin{tabular}{l|l|l|l}
$\begin{array}{l}\text { Case Reports in } \\
\text { Ophthalmology }\end{array}$ & $\begin{array}{l}\text { Case Rep 0phthalmol 2010;1:1-4 } \\
\text { Dol: } 10.1159 / 000313788\end{array}$ & Published online: May 12, 2010 & $\begin{array}{l}\text { ○ 2010 S. Karger AG, Basel } \\
\text { ISSN 1663-2699 } \\
\text { www.karger.com/cop }\end{array}$ \\
\hline
\end{tabular}

Bullous pemphigoid (BP) is the most common subepidermal autoimmune blistering disease. It is characterized histologically by subepidermal blisters and immunopathologically by deposition of autoantibodies and complement components along the epidermal basement membrane [1]. Most patients have circulating autoantibodies directed against two proteins: a $230 \mathrm{kDa}$ hemidesmosome component and a $180 \mathrm{kDa}$ lamina lucida component, both from the dermoepidermal junction [1,2]. BP typically affects persons after the seventh decade of life. The annual incidence is estimated at 6 to 30 per one million population. Recent higher estimates of BP rates may be related to improved diagnosis using modern laboratory techniques. So far, there is no indication for a geographic predilection of the disease [3].

\section{Case Report}

A 70-year-old male patient was admitted to the intensive care unit (ICU) with BP and sepsis. The patient's history was significant for fundus fluorescein angiography (FFA) 2 months prior to diagnosis of senile macular degeneration. The procedure was complicated by fluorescein extravasation at the antecubital region. At that time, the patient experienced pruritus and erythema that began at the wrists and spread quickly to cover the entire body. His past medical history was significant for essential hypertension, glaucoma, and senile macular degeneration. His medications included oral metoprolol 50 $\mathrm{mg}\left(\right.$ Beloc $\left.^{\circledR}\right)$, oral aspirin $100 \mathrm{mg}\left(\right.$ Coraspin $\left.^{\circledR}\right)$, and brimonidine tartrate $0.2 \%$ (Alphagan ${ }^{\circledR}$ ) ophthalmic solution. The patient also reported a history of allergy to human albumin solution (Plamasteril ${ }^{\circledR}$; Abbott), which he had received during bypass surgery 15 years before.

On dermatological examination, erythematous patches were present on the scalp, chest and anogenital region. Vesicles and tense bullae were present on all extremities (ig. 1 ). The patient was treated for presumed BP with daily oral methylprednisolone $48 \mathrm{mg}$, topical clobetasol dipropionate 0.05\% cream (Dermovate ${ }^{\circledR}$; Glaxo SmithKline), and topical 4\% urea lotion (Excipial Lipo ${ }^{\circledR}$; Orva).

A complete blood count revealed relative eosinophilia. Punch biopsies were performed of the affected area. Histopathologic examination revealed subepidermal blistering and dermal infiltrates of mononuclear cells and eosinophils. Focal areas of collagen flame figures were also noted. The dermalepidermal junction showed direct immunofluorescence linear reactivity for C3c and IgG. Salt extraction testing was consistent with BP.

Regression of the lesions began at day 6, at which time daily oral azathioprine $150 \mathrm{mg}\left(\operatorname{Imuran}^{\circledR}\right)$ was added. Following resolution of all lesions, the patient was discharged with prescriptions for oral methylprednisolone $40 \mathrm{mg}$, topical $4 \%$ urea lotion (Excipial Lipo ${ }^{\circledR}$; Orva) and oral azathioprine $\left(\right.$ Imuran $^{\circledR}$ ) $150 \mathrm{mg}$ daily. One month later, he was admitted to the ICU with sepsis secondary to urinary tract infection due to underlying decreased immune response. He died in the ICU from cardiac failure 2 weeks later.

\section{Discussion}

There has been considerable progress in understanding the physiopathology of $\mathrm{BP}$ during the past two decades. Nevertheless, BP frequently presents a diagnostic and therapeutic challenge. Several cases of BP in patients with diabetes mellitus, inflammatory bowel disease, rheumatoid arthritis, Hashimoto's thyroiditis, dermatomyositis, lupus erythematosus, myasthenia gravis and autoimmune thrombocytopenia have been reported $[3,4]$.

Although medications have been implicated in the development of BP [5], the mechanisms by which drugs can cause BP are unclear. One hypothesis is that drugs may trigger BP in patients with underlying genetic susceptibility, either by modifying the immune response or by altering the antigenic properties of the epidermal basement membrane [1]. A case control study assessing long-term drug use and development of BP 


\begin{tabular}{l|l|l|l}
$\begin{array}{l}\text { Case Reports in } \\
\text { Ophthalmology }\end{array}$ & $\begin{array}{l}\text { Case Rep 0phthalmol 2010;1:1-4 } \\
\text { Dol: } 10.1159 / 000313788\end{array}$ & & $\begin{array}{l}\text { Published online: May 12, } 2010 \\
\text { ISSN 1663-2699 Karger AG, Basel } \\
\text { www.karger.com/cop }\end{array}$ \\
\hline
\end{tabular}

showed that diuretics (particularly aldosterone antagonists) and neuroleptics were used more frequently by BP patients than control patients [1]. Because of these associations, potential drug causes should be considered in all BP patients.

Fluorescein angiography is a relatively safe procedure, with a risk profile comparable to that of other intravenous radiocontrast media angiography $[6,7]$. Sodium fluorescein is a low-molecular-weight, highly water-soluble compound with fluorescent properties. Because of the physical properties of fluorescein, it is routinely used for medical and laser treatment of chorioretinal diseases. The pathogenic and immune mechanisms that cause adverse reactions in $5 \%$ of patients receiving intravenous fluorescein are unknown. Adverse drug reactions to fluorescein are classified as mild, moderate, severe, and fatal [6]. Severe adverse reactions (0.05\%) include cardiovascular shock, myocardial infarction, laryngeal edema, and bronchospasm, and require prolonged, intensive care [7].

This patient had a history of allergy to a colloidal plasma substitute. These substitutes produce early and late allergic reactions due to starch components. Patients with a previous reaction to colloidal plasma substitute have a $48 \%$ incidence of adverse events with subsequent tests. Although these rates are obviously high, we have no recent studies about the present rates $[8,9]$.

Adverse reactions following intravenous fluorescein are very unusual, but a history of dye allergy, diabetes, or systemic arterial hypertension increases the risk of allergic reaction to fluorescein [6-8]. Prophylactic treatment, fluorescein desensitization or oral fluorescein angiography should be considered for high-risk patients [10]. Providers should be prepared to manage potential serious adverse reactions. Other imaging techniques, like optical coherence tomography, should be considered as an alternative in selected cases. To our knowledge, this is the first reported case of fluorescein-induced BP in a patient with colloidal plasma substitute allergy. The association between fundus fluorescein angiography and BP should be further investigated with a formal epidemiologic study.

Fig. 1. Photo of erythematous target-like lesions on the wrist of the patient.

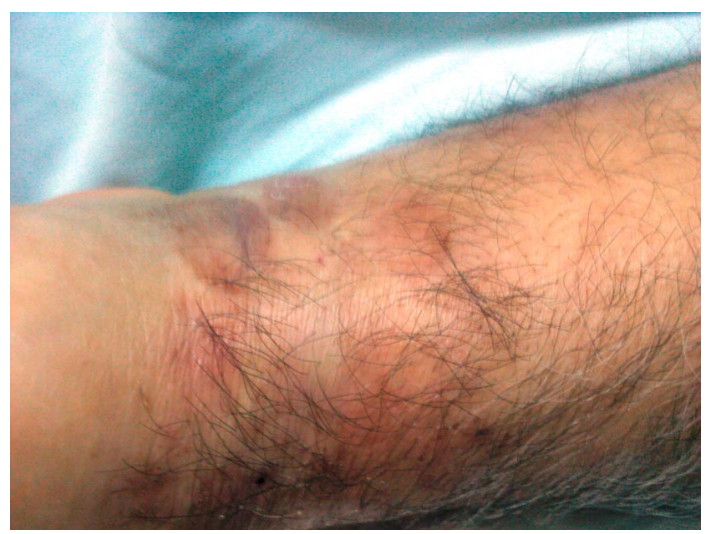




\begin{tabular}{l|l|l|l}
$\begin{array}{l}\text { Case Reports in } \\
\text { Ophthalmology }\end{array}$ & $\begin{array}{l}\text { Case Rep 0phthalmol 2010;1:1-4 } \\
\text { D0I: } 10.1159 / 000313788\end{array}$ & Published online: May 12, 2010 & $\begin{array}{l}\text { 2010 S. Karger AG, Basel } \\
\text { ISSN 1663-2699 } \\
\text { www.karger.com/cop }\end{array}$ \\
\hline
\end{tabular}

\section{References}

1 Bastuji-Garin S, Joly P, Picard-Dahan C, et al: Drugs associated with bullous pemphigoid: a case-control study. Arch Dermatol 1996;32:272-276.

2 Mueller S, Klaus-Kovtun V, Stanley JR: A $230-\mathrm{kD}$ basic protein is the major bullous pemphigoid antigen. J Invest Dermatol 1989;92:33-38.

3 Rzany B, Weller N: Epidemiology of autoimmune skin disorders; in Hertl M (ed): Autoimmune Diseases of the Skin. Wien, New York, Springer Verlag, 2005, pp $21-38$.

4 Di Zenzo G, Marazza G, Borradori L: Bullous pemphigoid: physiopathology, clinical features and management. Adv Dermatol 2007;23:257-288.

5 Vassileva S: Drug-induced pemphigoid: bullous and cicatricial. Clin Dermatol 1998;16:379-387.

6 Zografos L: International survey on the incidence of severe or fatal complications which may occur during fluorescein angiography. J Fr Ophtalmol 1983;6:495506.

7 Kwiterovich KA, Maguire MG, Murphy RP, Schachat AP, Bressler NM, Bressler SB, Fine SL: Frequency of adverse systemic reactions after fluorescein angiography. Results of a prospective study. Ophthalmology 1991;98:1139-1142.

8 Oral fluorography. The Oral Fluorescein Study Group. J Am Optom Assoc 1985;56:784-792.

-9 Celik I, Duda D, Stinner B, Kimura K, et al: Early and late histamine release induced by albumin, hetastarch and polygeline: some unexpected findings. Inflamm Res 2003;52:408-416.

10 Ellis PP, Schoenberger M, Rendi MA: Antihistamines as prophylaxis against side reactions to intravenous fluorescein. Trans Am Ophthalmol Soc 1980;78:190-205. 